\title{
実船運航データに基づく遭遇波向きの推定について
}

\author{
井関 俊夫*・田尾 茂郎***大津 皓平*
}

\section{Directional Wave Analysis Based on Actual Voyage Data}

\author{
Toshio ISEKI, Shigeo TAO and Kohei OHTSU
}

\begin{abstract}
Bayesian modelling procedure is applied to an inverse problem of how to estimate directional wave spectra from actual ship motion data. The data were recorded by the Voyage Data Recorder equipped on a real container carrier which was put on the North Pacific Line. As for the ordinary merchant ships, it is very difficult to know the actual parameters of rolling motion, such as natural periods, dumping coefficients and metacentric heights GM. And, it is almost impossible to get the hull form offset data which is required for the accurate calculation of the ship motion response functions. Therefore, it is the main purpose of this paper to clarify the availability of the Bayesian modelling procedure to the inverse problem under the unreliable conditions.

Compared with the wave direction measured by visual observations, it has shown that the estimated directional wave spectra have some peaks in the observed wave direction. This concludes that the Bayesian modelling procedure is a powerful tool for estimating the wave direction.
\end{abstract}

\section{1. 緒言}

波浪は船体に動摇を引き起こす外力の一つであり、船舶の運航効率に大きな影響を与える要素の一つで ある。船舶が遭遇する波浪を正確に予測あるいは把握することは、船舶設計者のみならず操船者にとって も船舶運航上の安全性、経済性という観点から重要な課題であるといえる。

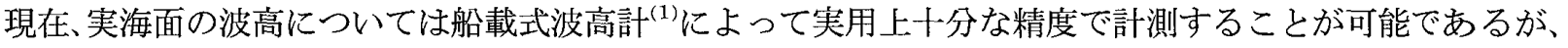
その波浪の方向性を推定することは容易ではない。一般に波浪の方向性に関する情報を得るためには、波 浪観測ブイや波高計アレイを用いて波高、波傾斜等の時系列を複数個同時計測する必要があるが、航行中 の船舶、特に一般商船においてはこれらのデータを得ることは事実上困難であると言える。このような困 難を克服するために、船体動摇データを用いて遭遇波浪の方向波スペクトラムを推定しようといら試みが いくつか行われている。用いられている推定計算法は最尤法 ${ }^{(2)} 、 \mathrm{MEP}^{(3)}$ ならびにBayes型モデルを用いた 方法(4)等であるが、実用段階にあるものは現在のところ存在しない。これらの中でBayes型モデルを用いた 推定法注、実海面の方向波スペクトラムに対して考えられる種々の性質を事前分布としてモデルに取り入 れることが可能であるため、十分な種類の同時計測データが得られない場合や信頼性の劣ったデータが混 ざっている場合においてもある程度精度の良い推定結果が期待できる。

本研究ではBayes型モデルを用いた方向波スペクトラム推定法を採用し、その実用性を検証することを試 みる。具体的には、実際に運航中のコンテナ船の船体運動データ(5)を用いて遭遇波浪の方向波スペクトラム を推定し、目視観測による結果と比較する。

\footnotetext{
* 正会員 東京商船大学（勇135 東京都江東区越中島2-1-6)
}

**正会員 運輸省航海訓練所（豪231 横浜市中区北仲通5-57） 
しかしながら、実際に運航中の商船を対象とした場合、本研究に限らず一般的に、

1）実船の詳細な船型データが入手できない。

2 ）運航中のトリム、GM、横摇れ減衰係数、横摇れ固有周期等のデータが不明である。

等のことが考えられるため、推定結果の精度に大きな影響を与える船体運動応答関数の計算が十分な精度 を持って行うことができないことになる。したがって、このような不十分な推定条件に対して、Bayes型モ デルを用いた方向波スペクトラム推定法がどの程度実用に耐えうるかを調べることが本研究の最大の目的 となる。

\section{Bayes型モデルを用いた方向波スペクトラム推定法}

本研究では実船上で計測された船載式波高計や 船体運動のデータから実海面の方向波スペクトラ ムの推定を試みるわけであるが、方向波スペクト ラムと船体運動との関係を模式的に表すと図 1 の ようになる。この図からわかるように、本研究の 課題は出力である船載式波高計や船体運動等のデ

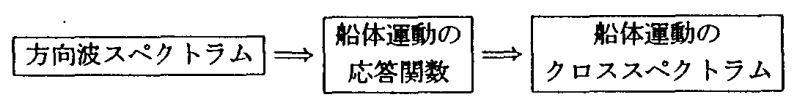

図 1 船体運動と方向波スペクトラムの関係 一タから入力である方向波スペクトラムを推定する、いわゆる逆問題を解くことであるといえる。このよ らな問題においては、伝達関数である船体運動応答関数の推定精度が結果の精度を左右するので、できる だけ笑際の運航状態に近い応答関数を求めておく必要があるが、一般商船においては正確なメタセンター 高さや横摇れ減衰係数のみならず、応答関数を求めるのに必要な船型データさえ入手困難な場合が少なく ないといえる。したがって、実際問題では精度の悪い船体運動応答関数からいかに正確な方向波スペクト ラムを推定するかが重要な課題となる。

Bayes的推論法はあらかじめ適当と思わ㞦るモデルの性質を仮定することが可能であり、推定精度の安定 性に有利な点を多く有するといえる。したがって、方向波スペクトラムの推定においても船体運動応答関 数の䛊差の影響を低く抑え、精度良く計算を行うことが期待できる。Bayes型モデルを用いた計算手順につ いては参考文献(4)で詳しく述べているので、ここではその概略を述べるにとどめる。

船体運動が波浪入力に対して線形态答であると仮定すると、ある波との出会い周波数 $f_{e}$ において方向波ス ペクトラム $E\left(f_{e}, \chi\right)$ と船体運動のクロススペクトラム $\phi m n\left(f_{e}\right)$ との間の関係は、一般に次のような式で 表される。

$$
\phi m n\left(f_{e}\right)=\int_{-\pi}^{\pi} H_{m}\left(f_{e}, \chi\right) H_{n}^{*}\left(f_{e}, \quad \chi\right) E\left(f_{e}, \chi\right) d \chi
$$

ここで、 $m$ と $n$ は縦摇れや横摇れなどの船体運動要素を表し、 $H_{m}\left(f_{e}, \chi\right) 、 H_{n}^{*}\left(f_{e}, \chi\right)$ はそれぞれの運 動要素の応答関数を表す。また、 $\chi$ は波との出会い角を表し、*は複素共役を表している。

この式を出会い角について適当に離散化すると次式のような線形回帰モデルに変換することができる。

$$
\mathbf{B}=\mathbf{A X}+\mathbf{W}
$$

ただし、Bは船体運動のクロススペクトラムマトリックスの要素 $\phi m n$ で構成されるベクトル、A 動の応答関数で構成される係数マトリックス、Xは出会い角で離散化された方向波スペクトラムから構成 される未知ベクトルを表す。また、Wは問題を統計的に取り扱うために挿入されたホワイトノイズを表す。

このモデルの尤度関数はWが分散 $\sigma^{2}$ の正規分布に従うと仮定すれば、

$$
L\left(\mathbf{X} \mid \sigma^{2}\right)=\left(\frac{1}{2 \pi \sigma^{2}}\right)^{\frac{L}{2}} \exp \left[-\frac{1}{2 \sigma^{2}}\|\mathbf{A X}-\mathbf{B}\|^{2}\right]
$$

で表される。ただし、\|｜|ははベクトルのノルムを表し、Lはベクトル $\mathbf{B}$ の要素数を表す。

赤池によって定式化されたBayes的推論法 ${ }^{(6)} に$ 従えば、方向波スペクトラムの最良の推定值を得るために はこのモデルの尤度関数 $L\left(\mathbf{X} \mid \sigma^{2}\right)$ と適当に仮定された事前分布 $P(\mathbf{X})$ との積を最大化するべクトル $\mathrm{X}$ 求めれば良いことになる。

事前分布としては種々のものが考えられるが、本研究では方向波スペクトラムの推定量が波との出会い 角と波周波数とに対して滑らかに变化すると規定する事前分布と方向波スペクトラムが過大に推定される 
傾向 ${ }^{(7)}$ を抑制するための事前分布を考慮した。したがって、一般的に次の形をとる尤度関数と事前分布との 積を最大化すれば良いことになる。

$$
\begin{aligned}
L\left(\mathbf{X} \mid \sigma^{2}\right) P(\mathbf{X}) & =\left(\frac{1}{2 \pi \sigma^{2}}\right)^{\frac{L}{2}}\left(\frac{u^{2}}{2 \pi \sigma^{2}}\right)^{\frac{M}{2}} \\
& \times \exp \left[-\frac{1}{2 \sigma^{2}}\left\{\|\mathbf{A X}-\mathbf{B}\|^{2}+\left.u^{2}\|\mathbf{D X}\|\right|^{2}\right\}\right]
\end{aligned}
$$

ここで、Dは事前分布を表すマトリックスであり、Mは事前分布を構成する式の数を表す。

(4)式の中の $u^{2}$ は八イパーパラメータと呼ばれるものであり、モデルの適合度と事前分布で与えられた性

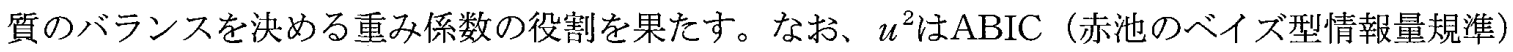

$$
A B I C=-2 \log \int L\left(\mathbf{X} \mid \sigma^{2}\right) P(\mathbf{X}) d \mathbf{X}
$$

の最小化によって客観的に決定することができる。

\section{3. 結果および考察}

\section{1 実船実験データの概要}

本研究で用いた船体運動データは北太平洋就航の定期コンテナ船（41,442総トン）を供試船（表 1 参照）

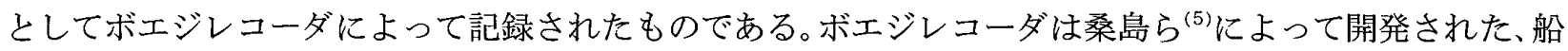
体運動ならびに海洋環境自動記録装置の名称であり、航空機のフライトレコーダと同等の役割を果たす航 海自動記録装置である。この装置によって計測されるデータの種類は表 2 に示されるとおりである。計測 は航海中の毎正時 (JST) から 10 分間、0.5秒のサンプリング周期で自動的に行われ、データはコンピュー タのハードディスクに蓄積されるようになっている。解析に用いたデータは1993年および1994年の冬季の 航海データの中から選ばれたものであり、図 2 にはその計測された時系列の一例を示している。なお、こ れらの時系列データの中で害際の波向き推定に用いたものは船首波高、船体縦摇れおよび横摇れの 3 種類 である。

\section{2 船型データの推定}

2.で述べたように、出力である船載式波高計や 船体運動等のデータから入力である方向波スペク トラムを推定する逆問題においては、伝達関数で ある船体運動の応答関数を精度良く推定する必要 がある。しかしながら、推定計算に必要な船型デ 一タは一般的に入手が困難であるため、本研究で は適当な類似船のオフセットデータをもとに供試 船の船型データを作成した。具体的には、類似船 の主要目が供試船の主要目に一致するように長さ、 幅、深さ方向の寸法比をすべてのオフセットデー 夕に乗じ、さらに排水量が一致するように船体中 央平行部を増減させた。船体運動の応答関数の計 算はN.S.M.を用いて行っており、2 次元流体力の 計算はclose-fit法によって行った。図 3 に 2 次元流 体力計算に用いた離散化された船型を示す。なお、 運航中の横摇れ減衰係数については全く資料がな いため、類似船のむのをそのまま使用している。

\section{3 方向波スペクトラムの推定結果}

図 4 に推定された方向波スペクトラムの一例を 示す。図は方向波スペクトラムを等高線で表した ものであり、半径方向が周波数、図面上側が船首

表 1 供試船の主要目

\begin{tabular}{|l|lr|}
\hline Registered Tonnage & Gross & $\begin{array}{l}41,442 \text { Tons } \\
\text { Net }\end{array}$ \\
\hline Length P.P. & & $230.00 \mathrm{~m}$ \\
\hline Breadth & & $32.22 \mathrm{~m}$ \\
\hline Depth & & $21.00 \mathrm{~m}$ \\
\hline Draught & Summer & $11.517 \mathrm{~m}$ \\
& Winter & $11.277 \mathrm{~m}$ \\
\hline Deadweight & Summer & 39,157 Tons \\
& Winter & 37,687 Tons \\
\hline
\end{tabular}

表 2 ボエジレコーダの計測項目

\begin{tabular}{|l|l|}
\hline 出会い実波高 & $\pm 10 \mathrm{~m}$ \\
\hline 船首上下加速度 & $\pm 2.5 \mathrm{G}$ \\
\hline ロール角 & $\pm 50 \mathrm{deg}$ \\
\hline ピッチ角 & $\pm 50 \mathrm{deg}$ \\
\hline ヒーブ加速度 & $\pm 1.0 \mathrm{G}$ \\
\hline サージ加速度 & $\pm 1.0 \mathrm{G}$ \\
\hline 風速 & 最大 $60 \mathrm{~m} / \mathrm{s}$ \\
\hline 風向 & $0 \sim 360 \mathrm{deg}$ \\
\hline
\end{tabular}




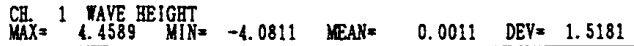

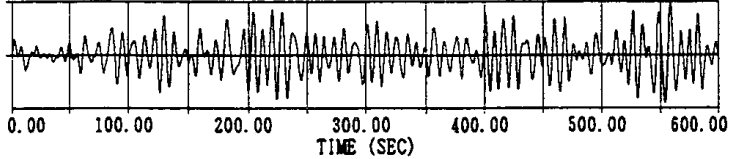

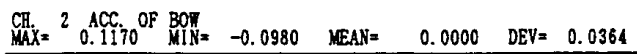
\begin{tabular}{|c|c|c|c|c|c|c|}
\hline & & & & & \\
\hline 0.00 & 100.00 & 200.00 & $\begin{array}{c}300.00 \\
\text { TINE (SEC) }\end{array}$ & 400.00 & 500.00 & 600.00 \\
\hline
\end{tabular}

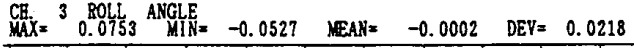

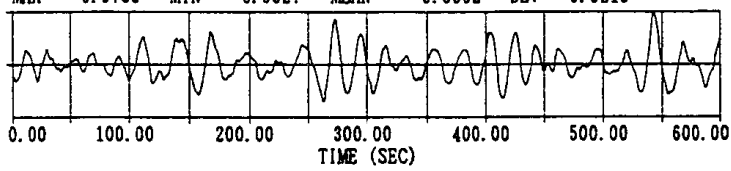

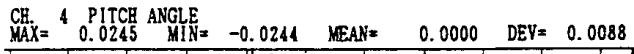
\begin{tabular}{|c|c|c|c|c|c|c|}
\hline & & & \\
0.00 & 100.00 & 200.00 & $\substack{300.00 \\
\text { TIXE (SEC) }}$ & 400.00 & 500.00 & 600.00 \\
\hline
\end{tabular}

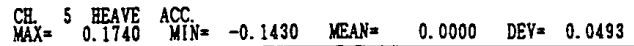
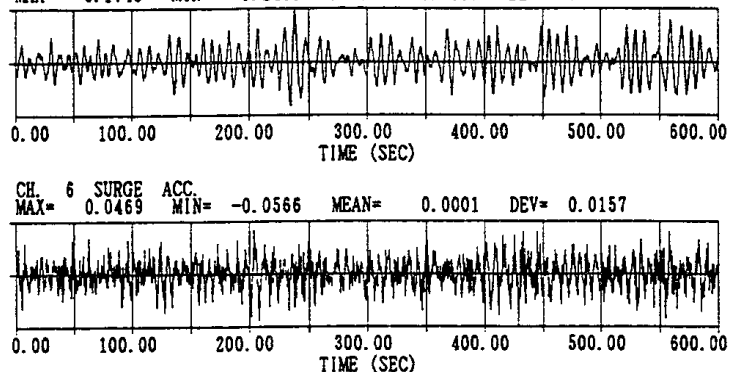

$\underset{M A X X}{C}{ }_{3}^{7.2965}$ SPEED

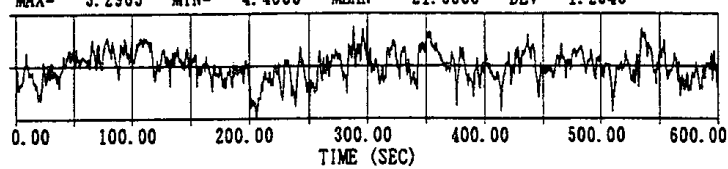

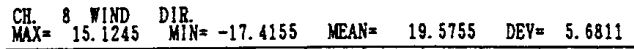

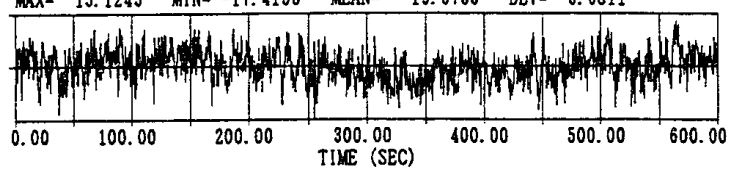

図 2 ボエジレコーダによって計測された時系列の一例

方向を表している。また、図中の矢印は目視観測 による波向きを示している。図を見ると、目視観 測による波向きとほぼ同じ方向に方向スペクトラ ムのピークが存在しており、本計算法が有効であ ることがわかる。本報告ではこの図に示されるよ うな推定計算を航海中に連続して収録されたデー タに対して行い、求められた方向波スペクトラム の最も高いピークの存在する方向を波の主方向と みなした。

図 5 に北太平洋航海中の1994年3月10日から3月 18日の9日間について、4 時間おきに方向波スペ クトラムを推定した結果を示す。図中には目視観 測による波向きと、推定された波の主方向が矢印 で示されている。図を見ると、目視観測と左右反 対に波向きが推定されている点がいくつかあるが、 この傾向は図4の結果においても見受けられる。 この推定の誤りの原因については次のように容易 に推測することができる。すなわち、推定計算に おいて左右舷の区別に関する情報を与えているも のは横運動である横摇れのデータのみであるから、 左右舷の推定誤りはそれに対応する横摇れの応答 関数に原因があるということである。実際の推定 計算に用いている船体運動の応答関数は、前述の ように類似船型から適当に作られた船型データと 横摇れ減衰係数等から求められているだけではな く、9日間の平均速力について計算されているの で、非線形性の強い横摇れに関してはかなり推定精度が低いと言わざるを得ない。

ここで仮に左右舷の区別を目視観測結果に従って行らことにすると、図 5 の結果は図 6 のように変化す

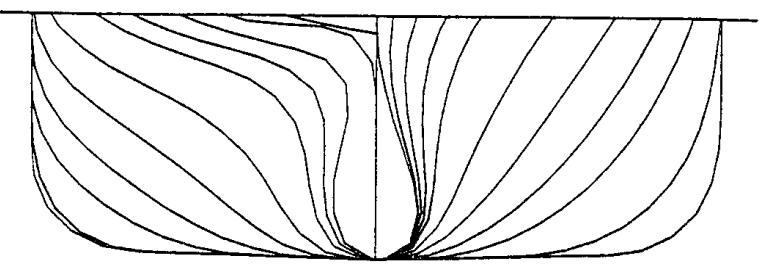

図 32 次元流体力計算のための船体表面分割の様子

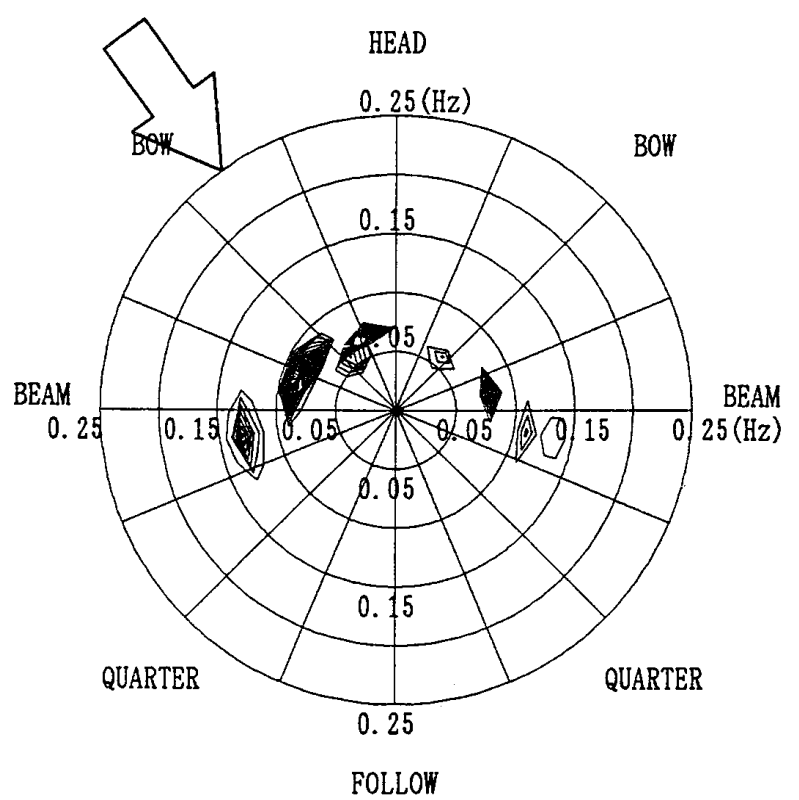

図 4 方向波スペクトラムの推定例 


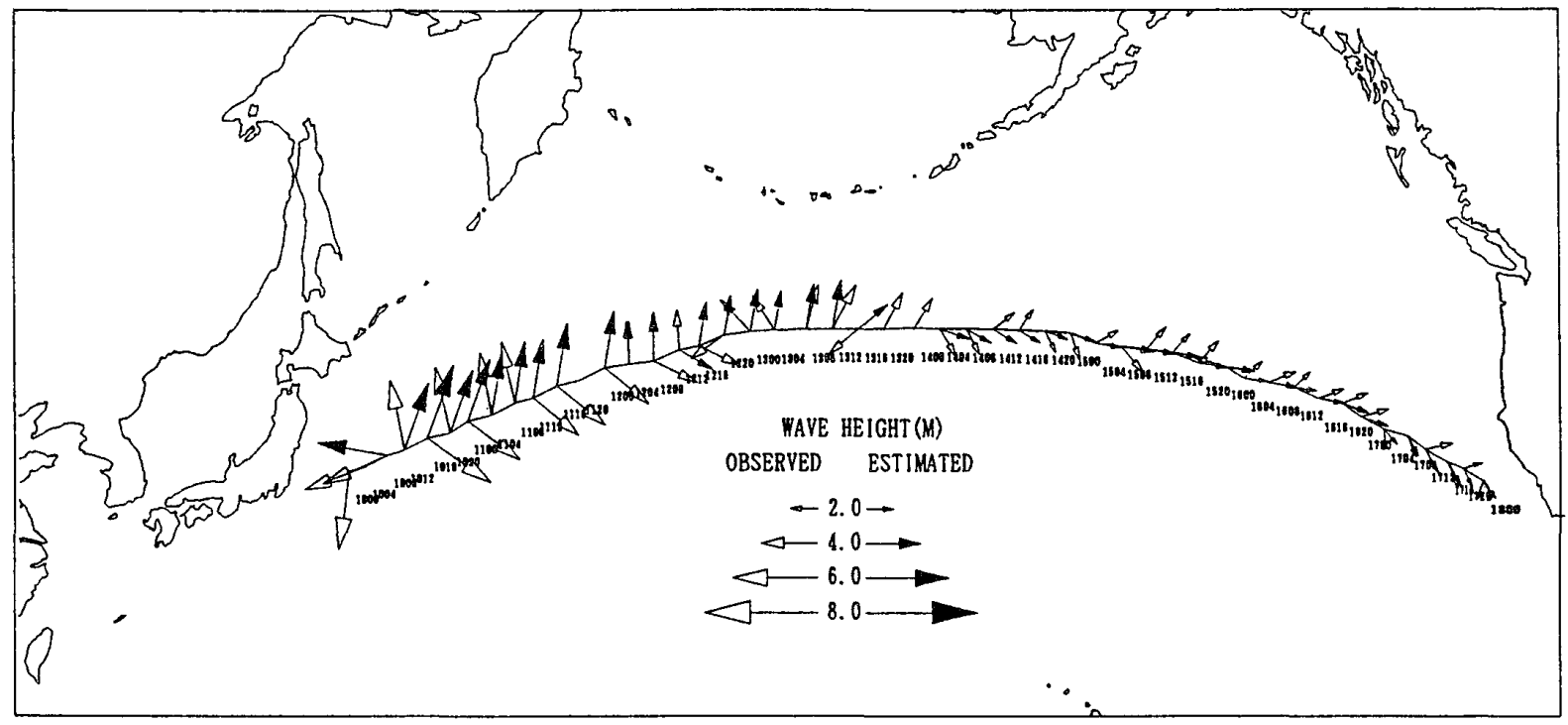

図 5 実船運航データを用いた波向き推定例

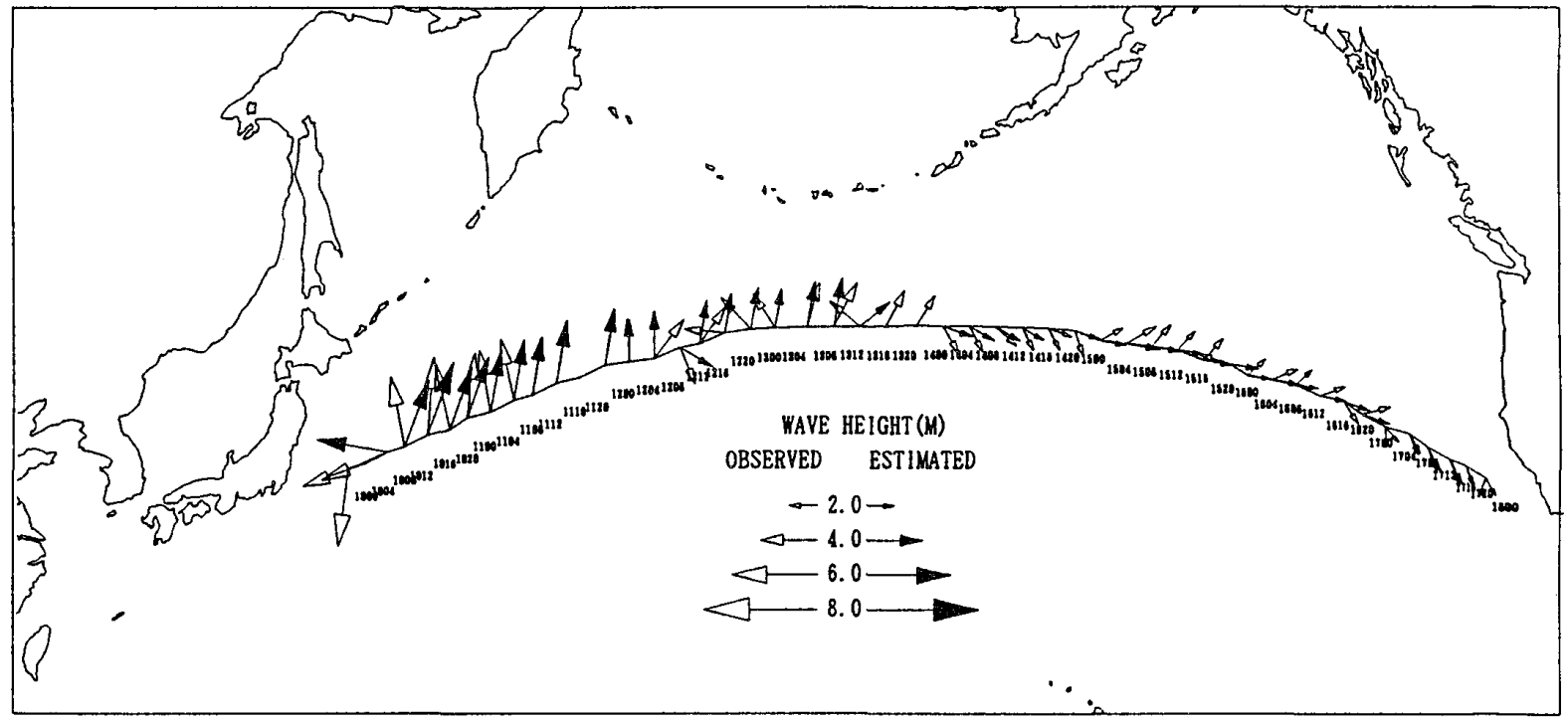

図 6 目視観測結果を用いて修正された波向き推定結果

る。当然ではあるが、推定された波の主方向は目 視観測結果と非常に良く一致することがわかる。

表 3 に図 5 と図 6 に示された波向きの推定精度 の比較を示す。表では推定された波の主方向と目 視観測による波向きの開きを推定䛊差として20度 毎に区切り、図 5 の左右䑪の判別をした場合を誤 差評価 1、図6の左右舷の判别を目視観測にした がった場合を誤差評価 2 として百分率で表してい る。ただし、サンプル数は45個である。この表に よると䛊差評価 1 では平均して40度から60度の推 定誤差があるのに対し、誤差評価 2 では全体の70パーセント近くが誤差40度以内におさまっていることが わかる。したがって、横摇れ応答関数の推定精度を向上させれば実用上十分な精度で波向きが推定できる といえる。

表 3 波向きの推定精度

\begin{tabular}{|c|c|c|}
\hline 推定誤差 (deg) & 誤差評価 1 & 詥差評洒 2 \\
\hline $0 \sim 20$ & $13.3 \%$ & $31.1 \%$ \\
\hline $20 \sim 40$ & $24.4 \%$ & $37.8 \%$ \\
\hline $40 \sim 60$ & $28.9 \%$ & $24.4 \%$ \\
\hline $60 \sim 80$ & $6.7 \%$ & $0.0 \%$ \\
\hline $80 \sim$ & $26.7 \%$ & $6.7 \%$ \\
\hline
\end{tabular}




\section{4. 結言}

本報告では、詳細な船型データと横摇れ減衰倸数等のパラメータが不明な実船運航データに対して、Bayes 型モデルを用いた方向波スペクトラム推定法がどの程度実用に耐え得るかを調べた。得られた結果をまと めると次のようになる。

1. 左右䑨の区別を目視観測に従えば約70\%の割合で、40度以内の精度で波向きを推定できる。

2. 波向きの左右舷の判別精度が悪い理由は、横摇れ減衰係数等のパラメータが不明であるため、横摇 れの応答関数の推定精度が低くなったためである。

一般に横摇れ減衰係数等のパラメータについては有効な簡易推定法が存在しないので、今後の課題とし

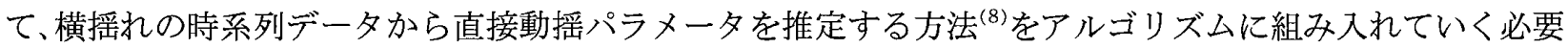
があると思われる。

\section{5. 謝 辞}

本研究の遂行に際して、東京商船大学桑島進教授ならびに岩坂直人助教授から快く穾船運航データを提 供して頂きました。心から感謝の意を表します。また、本論文の作成に当たりご協力下さいました織田美 千子さんに厚く御礼申し上げます。

\section{参 考 文 献}

（1）安田明生,他：マイクロ波を用いた舶用簡易波高計の開発, 日本航海学会論文集, 第66号, pp.31-38, 1982.

(2) 平山次清, 他 : 方向波スペクトルのハイブリッド型船上計測法開発, 日本造船学会論文集, 第180号, pp.295-309, 1996.

（3）吉元博文, 他: 航走する船舵が遭遇する方向波スペクトルの推定法について, 日本造船学会論文集, 第176号, pp.107-116, 1994.

（4）井関俊夫，他：船体運動データを用いた方向波スペクドルのBayes推定（第 2 報), 日本造船学会論文 集，第176号，pp.95-105，1994.

(5) 桑島 進, 他：ボエジレコーダ（航海自動記録装置）の開発研究，日本航海学会論文集，第94号, pp. 219-230, 1995.

(6) Akaike, H. : Likelihood and Bayes procedure, Bayesian Statistics (Bernardo, J.M., De Groot, M.H., Lindley, D.U. and Smith, A.F.M. eds.) University Press, Valencia, pp.143-166, 1980.

（7）井関俊夫，他：船体運動データを用いた方向波スペクトルのBayes推定，日本造船学会論文集，第172 号, pp.17-25, 1992.

(8) 大津皓平, 他：実船データによる動摇パラメータの統計的推定 一連続型自己回㷌モデルの応用一, 日本造船学会論文集, 第165号, pp.181-191， 1989.

\section{質 疑 応 答}

斎藤勝彦 (神戸商船大学) : rollの応答関数推定精度の問題で、方向の推定精度が悪くなっているようです が、あえてrollのデータを使わずpitchのみのデータで推定するとどうなるのでしょらか。

井関俊夫：左右舷の判別を行ら横運動データがなくなるわけですから左右のどちらから波が来ているのか がわからなくなります。しかし、左右舷の区別を行わないで良いのならば波向きの推定は可能です。横 摇れデータの有無が波向き推定精度に及ぼす影響は、横摇れ応答関数の推定精度によりますので、精度 の相当低い横摇れ応答関数ならば、横摇れデータを用いない方が有利になる場合もあると思われます。

久保雅義（神戸商船大学）：太平洋ではうねりと風波があると思います。そのような場での波向き予測はど のようにすればよいのでしょうか。結果はうねりと風波のどちらをとらえるのでしょらか。それとも両 者の平均をとらえるのでしょうか。

井関俊夫 : 船体は非常に精度の悪い波浪計ですから、波向きの推定計算では船体が良く摇れる波をとらえ ると思われます。したがって、一般的にはらねりを良くとらえると思います。 